Division of Geological \& Geophysical Surveys

RAW-DATA FILE 2015-4

\title{
GEOCHEMICAL REANALYSIS OF HISTORICAL U.S. GEOLOGICAL SURVEY SEDIMENT SAMPLES FROM THE INMACHUK, KUGRUK, KIWALIK, AND KOYUK RIVER DRAINAGES, GRANITE MOUNTAIN, AND THE NORTHERN DARBY MOUNTAINS, BENDELEBEN, CANDLE, KOTZEBUE, AND SOLOMON QUADRANGLES, ALASKA
}

by

Melanie B. Werdon, Matthew Granitto, and Jaime S. Azain

$\$ 4.00$

June 2015

THIS REPORT HAS NOT BEEN REVIEWED FOR TECHNICAL CONTENT OR

FOR CONFORMITY TO THE EDITORIAL STANDARDS OF DGGS
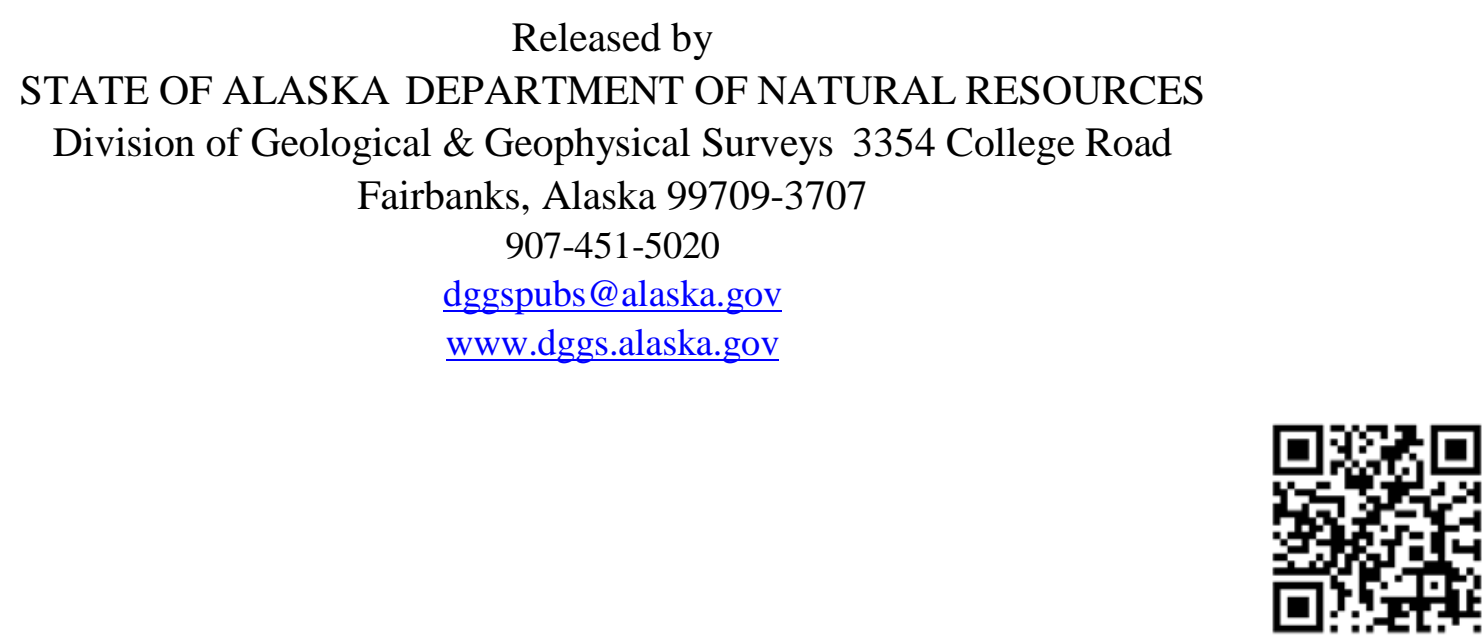



\title{
GEOCHEMICAL REANALYSIS OF HISTORICAL U.S. GEOLOGICAL SURVEY SEDIMENT SAMPLES FROM THE INMACHUK, KUGRUK, KIWALIK, AND KOYUK RIVER DRAINAGES, GRANITE MOUNTAIN, AND THE NORTHERN DARBY MOUNTAINS, BENDELEBEN, CANDLE, KOTZEBUE, AND SOLOMON QUADRANGLES, ALASKA
}

\author{
by \\ Melanie B. Werdon ${ }^{1}$, Matthew Granitto², and Jaime S. Azain² \\ ${ }^{1}$ Alaska Division of Geological \& Geophysical Surveys \\ ${ }^{2}$ U.S. Geological Survey, Central Mineral and Environmental Resources Science Center
}

\section{INTRODUCTION}

The State of Alaska's Strategic and Critical Minerals (SCM) Assessment project, a State-funded Capital Improvement Project (CIP), is designed to evaluate Alaska's statewide potential for SCM resources. The SCM Assessment is being implemented by the Alaska Division of Geological \& Geophysical Surveys (DGGS), and involves obtaining new airborne-geophysical, geological, and geochemical data. As part of the SCM Assessment, thousands of historical geochemical samples from DGGS, U.S. Geological Survey (USGS), and U.S. Bureau of Mines archives are being reanalyzed by DGGS using modern, quantitative, geochemical-analytical methods. The objective is to update the statewide geochemical database to more clearly identify areas in Alaska with SCM potential.

The USGS is also undertaking SCM-related geologic studies in Alaska through the federally funded Alaska Critical Minerals cooperative project. DGGS and USGS share the goal of evaluating Alaska's strategic and critical minerals potential and together created a Letter of Agreement (signed December 2012) and a supplementary Technical Assistance Agreement (\#14CMTAA143458) to facilitate the two agencies' cooperative work. Under these agreements, DGGS contracted the USGS in Denver to reanalyze historical USGS sediment samples from Alaska.

For this report, DGGS funded reanalysis of 653 historical USGS sediment samples from the statewide Alaska Geochemical Database Version 2.0 (AGDB2; Granitto and others, 2013). Samples were chosen from an area covering portions of the Inmachuk, Kugruk, Kiwalik, and Koyuk river drainages, Granite Mountain, and the northern Darby Mountains, located in the Bendeleben, Candle, Kotzebue, and Solomon quadrangles of eastern Seward Peninsula, Alaska (fig. 1). The USGS was responsible for sample retrieval from the National Geochemical Sample Archive (NGSA) in Denver, Colorado through the final quality assurance/quality control (QA/QC) of the geochemical analyses obtained through the USGS contract lab. The new geochemical data are published in this report as a coauthored DGGS report, and will be incorporated into the statewide geochemical databases of both agencies. 


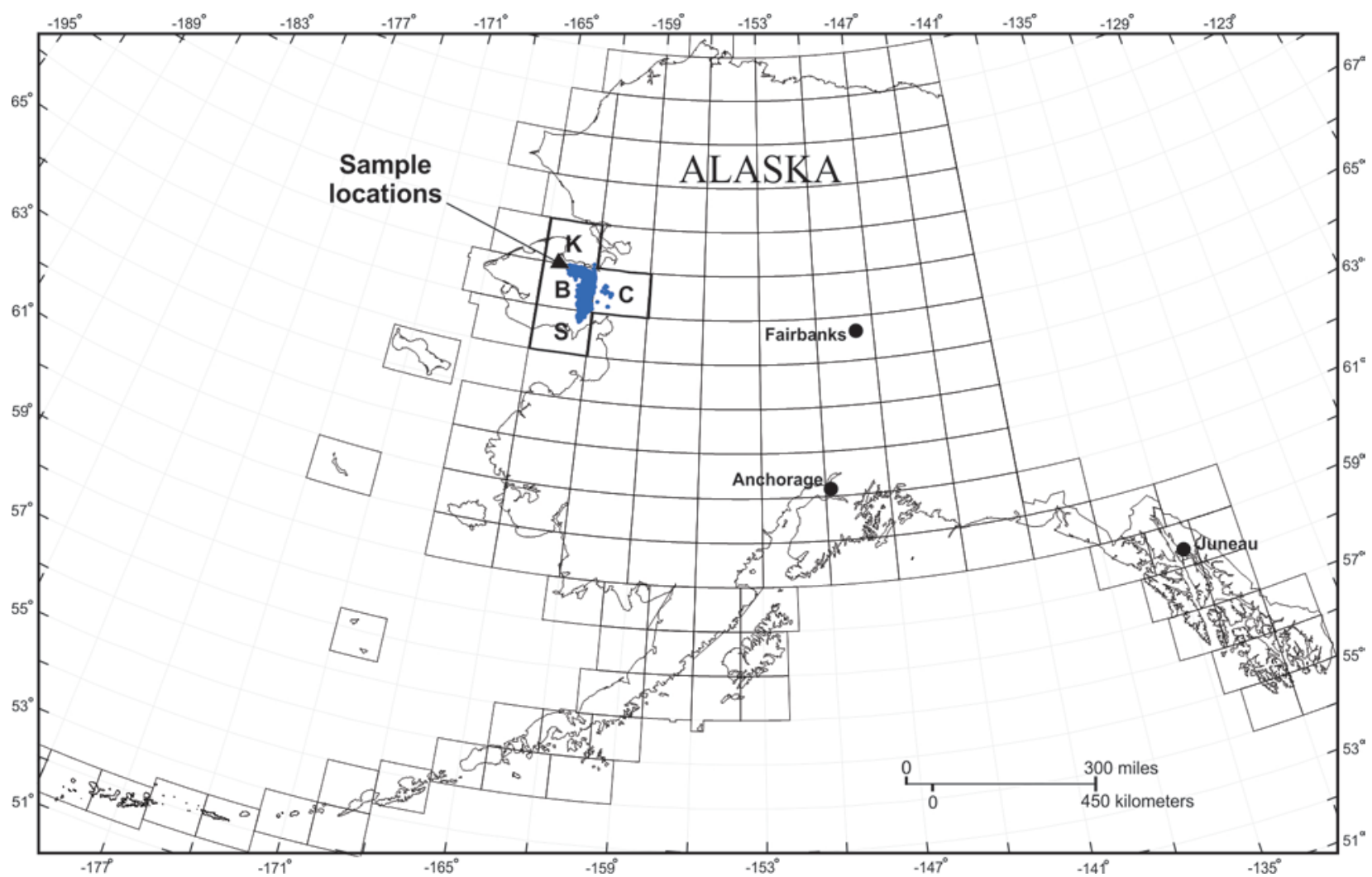

Figure 1. Map showing the location of reanalyzed sediment samples in the Inmachuk, Kugruk, Kiwalik, and Koyuk river drainages, Granite Mountain area, and the northern Darby Mountains, located in the Bendeleben (B), Candle (C), Kotzebue (K), and Solomon (S) quadrangles of eastern Seward Peninsula, Alaska. 


\section{DOCUMENTATION OF METHODS}

\section{SAMPLE COLLECTION}

The 653 Alaska sediment samples of interest were collected as part of several USGS and U.S. Department of Energy projects. Details of initial sample collection and analytical methods for these historical samples have been compiled into a single digital database, AGDB2 (Granitto and others, 2013). The original analyses for most of these samples were previously published, and the citations for the original results are included in the References and Original Data Sources section.

Location data for each sample are presented in latitude and longitude coordinates in decimal degrees with NAD27 datum and Clarke 1866 spheroid; resolution is variable, and ranges from 5-digit GPS precision to others with less precision. Original locations were collected with NAD27 datum and Clarke 1866 spheroid; original location information is documented in Granitto and others (2013).

\section{SAMPLE PREPARATION}

Historical sediment samples were retrieved from the National Geochemical Sample Archive (NGSA) in Denver by USGS staff, then weighed, ground to -200 mesh and, where sufficient material was available, split into aliquots needed for analyses. Leftover material was re-archived at the NGSA. Sample splits were submitted to the USGS contract lab (SGS Minerals Services, Lakefield, Canada) for analysis.

\section{ANALYTICAL METHODS}

Where sufficient sample material was available, sample splits were analyzed for gold (Au), palladium (Pd), platinum (Pt), tellurium (Te), and 55 major and trace elements. Samples previously analyzed for Au, Pd, and Pt by fire assay were not reanalyzed as part of this project because the historical analyses used the same technique as modern analytical methods.

Data Validation: Analytical results obtained from samples submitted to the contract laboratory (SGS) must pass through two levels of data validation. The first level of quality control checks occurs at SGS Minerals Services. SGS is accredited to ISO/IEC 17025:2005 standards and conforms to requirements of CAN-P-4E and CAN-P-1579 (Standards Council of Canada, 2015). The laboratory's quality control protocol is to insert a reagent blank and a reference sample material with every batch of 20 samples to measure the analytical accuracy. Duplicate samples are analyzed at the end of the sample set to measure analytical variance as well as sample variance. Data passing the quality control criteria are sent to the USGS and imported into its Laboratory Information Management System (LIMS).

The second level of data validation is performed at the USGS. All samples submitted to SGS are accompanied by a set of USGS in-house reference samples (blinds) submitted at the rate of 10 percent. Using a program in LIMS, the data for the reference samples are evaluated by comparing the "obtained" analytical value to the "expected" value for each element. The values must fall within the range of acceptance, which varies between \pm 5 percent to \pm 20 percent depending on the analytical method. Analytical results for samples associated with the accepted quality control data are then released to the sample submitter. Samples associated with rejected quality control data are reanalyzed by SGS. In this study, there weren't any samples associated with rejected quality control data, and therefore no samples were reanalyzed.

The following list describes each analytical method, sample weight (in grams), detection limits, and acceptable analytical performance criteria:

a. Method 20 — Gold (Au), Platinum (Pt), and Palladium (Pd). Gold, Pt, and Pd content were determined in geologic materials by Inductively Coupled Plasma-Mass Spectrometry (ICP-MS) after collection by fire assay. 
An assay ton (30 grams) was weighed into a crucible with 150 grams of flux and mixed. One mg of silver nitrate was added and covered with borax, and then placed in the furnace for 45 minutes at $1,080^{\circ} \mathrm{C}$. The melt was poured into a cast-iron mold, cooled, and hammered to free the lead button from the slag. The lead button was placed on a cupel and heated at $950^{\circ} \mathrm{C}$ until all the lead was removed. The resulting doré bead was dissolved in a mixture of nitric acid and hydrochloric acid and heated in a water bath. The final solution was adjusted to 10 $\mathrm{ml}$ and introduced into the ICP-MS. The lower reporting limits are $1 \mathrm{ppb}$ for Au and Pd, and $0.5 \mathrm{ppb}$ for Pt. The upper limit for all elements is $10,000 \mathrm{ppb}$. Data were deemed acceptable if recovery of gold, platinum, and palladium was \pm 20 percent at five times the lower limit of detection (LOD) and the calculated Relative Standard Deviation (RSD) of duplicate samples was no greater than 20 percent.

b. Method 22-55-Element ICP-AES-MS sodium peroxide sinter. Fifty-five major (except Si and Na), rareearth, and trace elements were determined in geologic materials by inductively coupled plasma-atomic emission spectrometry (ICP-AES) and ICP-MS. The $0.10 \mathrm{~g}$ sample was decomposed using a sodium-peroxide sinter at $450^{\circ} \mathrm{C}$. The resultant cake was leached with water for a minimum of 4 hours, and acidified with nitric acid. After an addition of tartaric acid, aliquots of the digested sample were aspirated into the ICP-AES and the ICP-MS. The concentrations of the optimal elements from the ICP-AES and ICP-MS were determined. Calibration on the ICP-AES was performed by standardizing with digested rock reference materials and a series of multi-element solution standards. The ICP-MS was calibrated with aqueous standards, and internal standards were used to compensate for matrix effects and internal drifts. Reporting limits for the 55 elements are presented in the tables accompanying this report. Data were deemed acceptable if recovery for all 55 elements was \pm 15 percent at five times the lower LOD and the calculated RSD of duplicate samples was no greater than 15 percent.

c. Method 13-Tellurium (Te). Tellurium content was determined by weighing $0.25 \mathrm{~g}$ of sample into a Teflon tube, adding a mixture of nitric, hydrofluoric, and perchloric acids and heating the sample. After the solution cooled, hydrochloric and nitric acids were added, and the sample was heated again, and then cooled. The samples were diluted and analyzed using hydride-generation atomic absorption spectrometry with an autoanalyzer and automated data collection system from Labtronics. The lower reporting limit for Te is $0.5 \mathrm{ppm}$ and the upper detection limit is 1,000 ppm. Data for Te were deemed acceptable if recovery of that element was \pm 20 percent at five times the lower LOD and the calculated RSD of duplicate samples was no greater than 20 percent.

\section{RESULTS}

This report includes the following components: A text report (PDF file), an analytical-data table (.xlsx file), a detection-limits table (.csv file), a metadata file (.htm) documenting additional details about the reanalysis project, and a ReadMe file (.htm), which provides an overview of files associated with this report. All files associated with this report are available from the DGGS website (doi:10.14509/29448).

In the analytical-data table, field names (column headers) show the element and the units in which they are reported. Where a numerical suffix is shown, this element was analyzed by more than one method. In the detection-limits table and the metadata file, documentation is provided to explain each field name, as well as additional details such as lab name and method codes, analytical-method types and documentation, and the upper and lower detection limits for each of the elements and methods. For a few elements, the laboratory reported values that are either above the upper detection limit or below the lower detection limit; these values were kept in the data table. For each element, for each sample, the analytical-data table either contains assay values, or it contains coded-value place holders (that is, null or blank = not analyzed; -1 = the element's assay result is less than the lower detection limit for the method; -2 = the element's assay result is greater than the upper detection limit for the method; $-3=$ composition of this sample makes detection impossible by this method; interference problems; $-4=$ sample was submitted to the laboratory, but insufficient sample material was available to conduct an analysis). 


\section{ACKNOWLEDGMENTS}

We appreciate the help of the following people: Timothy Hayes and Coleen Chaney in writing the Technical Assistance Agreement for this project; and Jeffrey L. Mauk and Bronwen Wang for reviewing this report and associated digital tables. Any use of trade, product, or firm names is for descriptive purposes only and does not imply endorsement by the U.S. Government.

\section{REFERENCES AND ORIGINAL DATA SOURCES}

Arbogast, B.F., O'Leary, R.M., Marchitti, M.L., and King, H.D., 1985, Analytical results and sample locality maps of stream-sediment and heavy-mineral-concentrate samples from the Solomon and Bendeleben quadrangles, Alaska: U.S. Geological Survey Open-File Report 85-144, 213 p. pamphlet and maps. Available at http://pubs.er.usgs.gov/publication/ofr85144

Elliott, R.L., and Miller, T.P., 1969, Results of stream-sediment sampling in the western Candle and southern Selawik quadrangles, Alaska: U.S. Geological Survey Open-File Report 69-89, 61 p. pamphlet and map. Available at http://pubs.er.usgs.gov/publication/ofr6989

Granitto, M., Schmidt, J.M., Shew, N.B., Gamble, B.M., and Labay, K.A., 2013, Alaska Geochemical Database Version 2.0 (AGDB2) - Including "best value” data compilations for rock, sediment, soil, mineral, and concentrate sample media: U.S. Geological Survey Data Series 759, 20 p. pamphlet and database, 1 DVD, accessed on April 25, 2014, at http://www.dggs.alaska.gov/pubs/id/25219.

Granitto, M., Bailey, E.A., Schmidt, J.M., Shew, N.B., Gamble, B.M., and Labay, K.A., 2011, Alaska Geochemical Database (AGDB) - Geochemical data for rock, sediment, soil, mineral, and concentrate sample media: U.S. Geological Survey Data Series 637, 11 p., appendices, metadata files, data files download, accessed on April 25, 2014, at http://www.dggs.alaska.gov/pubs/id/23579.

King, H.D., Sutley, S.J., O'Leary, R.M., McDougal, C.M., and Duttweiler, K.A., 1982, Analytical data for minus80-mesh stream-sediment samples collected during 1981 from the Solomon and Bendeleben quadrangles, Alaska: U.S. Geological Survey Open-File Report 82-964, 46 p. pamphlet, 2 over-size sheets and maps. Available at http://pubs.er.usgs.gov/publication/ofr82964

Miller, T.P., Elliott, R.L., Grybeck, D.G., and Hudson, T.L., 1971, Results of geochemical sampling in the northern Darby Mountains, Seward Peninsula, Alaska: U.S. Geological Survey Open-File Report 71-211, 12 p. pamphlet and map. Available at http://pubs.er.usgs.gov/publication/ofr71211

Miller, T.P., and Grybeck, D.G., 1973, Geochemical survey of the eastern Solomon and southeastern Bendeleben quadrangles, Seward Peninsula, Alaska: U.S. Geological Survey Open-File Report 73-189, 115 p. pamphlet and map. Available at http://pubs.er.usgs.gov/publication/ofr73189

Nelson, C.H., and Hopkins, D.M., 1972, Sedimentary processes and distribution of particulate gold in the northern Bering Sea: U.S. Geological Survey Professional Paper 689, 27 p. pamphlet and plate. Available at http://pubs.er.usgs.gov/publication/pp689

Smith, S.M., 1997, National Geochemical Database reformatted data from the National Uranium Resource Evaluation (NURE) Hydrogeochemical and Stream Sediment Reconnaissance (HSSR) program: U.S. Geological Survey Open-File Report 97-492, Version 1.40, some Version 1.41. Available at http://pubs.er.usgs.gov/publication/ofr97492

Standards Council of Canada, 2015, Criteria and procedures for laboratory accreditation; Standards Council of Canada, https://www.scc.ca/en/about-scc/publications/criteria-and-procedures/laboratory-accreditation, accessed on June 9, 2015.

U.S. Geological Survey, 2008, The National Geochemical Survey, Version 5.0; database and documentation: U.S. Geological Survey Open-File Report 2004-1001. Available at http://pubs.usgs.gov/of/2004/1001/ 